Uniwersytet im. Adama Mickiewicza, Poznań

\title{
Projekt ustawy o dzialalności lobbyingowej z 11 marca 2003 r.
}

\section{W} ostatnim czasie pojawiają się coraz głośniej artykułowane wątpliwości co do motywów i mechanizmów powstawania wybranych legislacji. W tym kontekście wymieniane jest zjawisko lobbyingu i to często w charakterze winowajcy i sprawcy takich patologicznych mechanizmów życia społecznego, jak chociażby korupcja. Wydaje się, że mamy tu do czynienia z całkowitym niezrozumieniem tej instytucji systemu demokratycznego. Dlatego celem niniejszego opracowania jest przybliżenie prawdziwego oblicza lobbyingu poprzez ukazanie rozwiązań prawnych funkcjonujących w tym zakresie w innych demokracjach, ale przede wszystkim na tym tle pokazanie najważniejszych założeń przygotowanego w Ministerstwie Spraw Wewnętrznych i Administracji projektu polskiej ustawy o działalności lobbyingowej.

Na wstępie wyjaśnić należy, że pod pojęciem lobbyingu ${ }^{1}$ rozumie się w doktrynie „działalność podejmowaną i prowadzoną przez grupy interesów, zwane też grupami nacisku ${ }^{2}$, w sferze stosunków politycznych, polegającą na wywieraniu presji na polityków parlamentarnych, członków najwyższego kierownictwa organów państwa, ale też na polityków regionalnych, samorządowych, a także na liderów i kierownictwo partii politycznych”3. Inni

1 W kwestii porównania terminów lobbying, public relations, public affairs, government relations patrz szerzej K. Jasiecki, M. Molęda-Zdziech, U. Kurczewska, Lobbing. Sztuka skutecznego wywierania wpływu, Kraków 2000, s. 39-44.

2 Co do pojęcia grup nacisku patrz szerzej G. Ponton, P. Gill, Introduction to politics, Oxford, Cambridge 1993, s. 135 oraz W. Ph. Shively, Power and Choice, An Introduction to political Science, Minnesota 1993, s. 231.

3 J. Muszyński, Leksykon marketingu politycznego, Wrocław 2001, s. 95, Power and Choice, pod red. W. Ph. Shively, Minnesota 1993, s. 229; zob. także Introduction to Politics, pod red. G. Ponton, P. Gill, Oxford, Cambridge 1993, s. 135 i n. oraz H. Izdebski, Samorzqdowy lobbying a kohabitacja rzqdu i samorzqdu terytorialnego, Warszawa 1999, s. 4; W. Kisiel, Miejsce lobbyingu i kohabitacji wśród metod działania samorzqdu terytorialnego, Warszawa 1999, s. 20. 
autorzy definiują to pojęcie jako „zbiór działań podejmowanych w celu wpływania na decyzje, które jeszcze nie zapadły"4. Przyznać jednak należy, że rzeczywiście w praktyce ustrojowej wielu państw niekiedy lobbying utożsamia się z korupcją (np. obiecywanie korzyści osobistych lub majątkowych w zamian za określone przywileje, przychylne ustawodawstwo $)^{5}$. Są to jednak przypadki, jak można wierzyć, odosobnione i nie mające $\mathrm{w}$ istocie nic wspólnego z lobbyingiem. Celem bowiem lobbyingu winna być legalna [podkr. J.S.] korekta politycznego procesu decyzyjnego, której wdrożenie sprzyjać będzie realizacji interesów grupowych ${ }^{6}$.

Źródłosłowem pojęcia lobbying jest wyraz pochodzący z języka angielskiego „lobby”, czyli korytarz. Było to bowiem miejsce wymiany informacji pomiędzy strukturami władzy i obywatelami, zwłaszcza parlamentarzystów z rzecznikami interesu ${ }^{7}$. W doktrynie można odnaleźć wiele podziałów działalności lobbyingowych dokonywanych według różnych kryteriów. Wyróżniamy lobbying defensywny i ofensywny, bezpośredni i pośredni ${ }^{8}$. Niektórzy autorzy mówią o tzw. lobbyingu jawnym, czyli działaniach informacyjnych polegających na dostarczeniu ekspertyz, organizacji seminariów, spotkań, akcji społecznych. Natomiast lobbying ukryty to po prostu działalność korupcyjna ${ }^{9}$.

Kolebką lobbyingu były Stany Zjednoczone Ameryki Północnej. Trudno się zatem dziwić, że tam przyjęto pierwsze na świecie rozwiązania prawne dotyczące tego zagadnienia, które dzisiaj uchodzić mogą za rozwiązania wręcz modelowe. Trzeba jednak przypomnieć, że jeszcze w 1877 r. konstytucja Stanu Georgia nazywała lobbying zbrodnią,

${ }^{4}$ K.Tarnawska, Rozwój lobbyingu w Unii Europejskiej, „Sprawy Międzynarodowe" 1999 , nr 3, s. 25.

${ }^{5}$ Rzetelność życia publicznego. Metody zapobiegania korupcji, pod red. J. Pope, Warszawa 1999, passim, a także J. Kurczewski, Korupcja a prawo do dobrego rzqdu, w: Korupcja w życiu społecznym, pod red. J. Kurczewskiego, B. Łaciak, Warszawa 2000, s. 9 i n.; J. Klich, Lobbying na rzecz matych $i$ średnich przedsiębiorstw, w: O lobbingu i nie tylko, Kraków 1998, s. 36; M. Zieliński, Możliwość rozwoju lobbingu dla MŚP $w$ Polsce, ibidem, s. 45.

${ }^{6}$ J. Sroka, Lobbying jako strategia promocji interesów grupowych, w: Marketing polityczny $w$ teorii i praktyce, s. 202.

${ }^{7}$ Ibidem, zob. także T. Kozłowski, Samorzqdowy lobbying a kohabitacja rzq̨du i samorzadu terytorialnego, Warszawa 1999, s. 14.

${ }^{8}$ K. Jasiecki, M. Molęda-Zdziech, U. Kurczewska, op. cit., s. 37.

9 J. Muszyński, Koszty funkcjonowania rynku politycznego, „Przegląd Politologiczny" 2000, nr 1-2, s. 80, a także tenże, Władza: pokusa i ryzyko, ibidem 1999, nr $1-2$, s. 51 i n. 
zasługującą ma karę więzienia. W 1852 r. Izba Reprezentantów zabroniła wstępu do budynku Kongresu dziennikarzom zainteresowanym rozstrzygnięciem konkretnej sprawy, a w 1867 r. zabroniono udziału w posiedzeniach byłym kongresmanom ${ }^{10}$. Ale już jedenaście lat później Izba Reprezentantów przyjęła rezolucję wymagającą ujawnienia działalności przez lobby ${ }^{11}$, a w 1890 r. w stanie Massachusetts ukonstytuował się ruch żądający rejestracji lobbystów. W 1929 r. już trzydzieści dwa stany miały odrębne ustawy regulujące tę problematykę ${ }^{12}$.

Zanim w 1946 r. na poziomie legislacji federalnej przyjęto ustawę regulującą działalność lobbyingową, czyli Akt o federalnej regulacji działalności lobbyingowej ${ }^{13}$, już w 1937 r. zobowiązano do ujawnienia działalności grup nacisku związanych z przemysłem okrętowym, a w 1938 r. wprowadzono obowiązek ujawnienia lobbyingu przez podmioty reprezentujące zagraniczne jednostki ${ }^{14}$. Ten akt normatywny dotyczył tylko bezpośrednich kontaktów z członkami Kongresu. Głównym celem ustawy z 1946 r. było ujawnienie działań lobbyingu, co przejawia się chociażby koniecznością rejestracji u Sekretarza Izby lub Senatu (należy wówczas wskazać zleceniodawcę oraz warunki, na jakich zostało się zaangażowanym). Zgodnie $\mathrm{z}$ tym aktem normatywnym lobbysta to osoba, która działa głównie po to, aby dopomóc uchwaleniu lub uchyleniu określonego ustawodawstwa. Ustawa wymagała także składania pod przysięgą kwartalnych raportów na temat otrzymywanych i wydatkowanych pieniędzy. Znaczenie tej ustawy osłabione zostało poprzez orzeczenie Sądu Najwyższego USA z 1954 r. (USA przeciwko Harris), które to z jednej strony potwierdziło zgodność tej ustawy z konstytucją USA, ale z drugiej strony ograniczało jej stosowanie tyko do przypadków, gdy lobbysta reprezentuje inny podmiot. Ustawa dotyczyć mogła tylko tych podmiotów, dla których głównym celem jest lobbying, a obowiązek rejestracji ustaw odnosi się tylko do tych lobbystów, którzy bezpośrednio kontaktują się z członkami Kongresu, ale już nie z ich asystentami ${ }^{15}$. Ustawę tę uzu-

10 K. Jasiecki, M. Molęda-Zdziech, U. Kurczewska, op. cit., s. 62.

11 Ibidem.

12 K. Zwierzchowski, Organizacje interesów grupowych a Kongres Stanów Zjednoczonych Ameryki, Katowice 1993, s. 332-351.

13 Ang. Federal Regulation of Lobbying Act - tzw. ustawa „LaFolette - Monroney".

14 K. Jasiecki, M. Molęda-Zdziech, U. Kurczewska, op. cit., s. 62.

15 K. Wójtowicz, Grupy nacisku w procesie tworzenia prawa, ,Acta Universitatis Vratislaviensis", Prawo, t. CXII, Wrocław 1984. 
pełniają dodatkowe regulacje normatywne, takie jak np. normy dotyczące zjawiska tzw. „drzwi obrotowych”, czyli doradzania grupom nacisku przez byłych urzędników Kongresu i administracji rządowej. Takie ograniczenie obowiązuje przez okres roku od zakończenia piastowania funk$\mathrm{cji}^{16}$. W tym kontekście wspomnieć tu należy o tzw. poprawce Byrda zakazującej finansowania przez budżet federalny działalności tego rodzaju oraz Lobbying Disclosure Act, który wszedł w życie 1 stycznia 1996 r. Ten ostatni akt normatywny doprecyzował niejasności pozostające po przyjęciu orzeczenia Sądu Najwyższego z 1954 r. Mianowicie pod pojęciem lobbysta rozumie się na mocy tego aktu normatywnego osobę, która poświęca więcej niż $20 \%$ czasu na tzw. kontakt lobbystyczny, czyli „każdą ustną, pisemną, elektroniczną formę komunikacji, aby wpłynąć na decydentów władzy wykonawczej, ustawodawczej w imieniu klienta w celu zredagowania, modyfikacji czy adaptacji federalnego przepisu, zredagowania, modyfikacji czy adaptacji programu polityki rządu USA, zarządzania czy też wcielania w życie programu lub polityki federalnej (nagrody, licencje, pożyczki, zezwolenia), a wreszcie nominacji, zatwierdzenia osoby na pozycję podlegającą zatwierdzeniu przez Senat"17. Ponadto w 1989 r. przyjęto ustawę o reformie etyki (Ethics Reform Act), wprowadzono ograniczenia w kwestii przyjmowania darowizn przez członków Kongresu. W konsekwencji nałożono obowiązek składania deklaracji finansowych i ujawnienia wszelkich korzyści. Od 1 stycznia 1996 r. zakazano przyjmować jakichkolwiek korzyści finansowych od osób zainteresowanych rozstrzygnięciem jakiejś sprawy ${ }^{18}$.

Wzorem ustawy amerykańskiej, podobne regulacje przyjęto w Kanadzie $^{19}$. Wprowadzono tam rozwiązanie, według którego wprowadza się podział na tzw. dwa szeregi lobbystów. W pierwszym szeregu umieszcza się profesjonalnych lobbystów i wymaga się od nich podania więcej informacji. W drugim szeregu lobbystów umieszcza się tych, którzy reprezentują własne grupy interesów, a wymogi formalne przy

${ }^{16}$ K. Jasiecki, M. Molęda-Zdziech, U. Kurczewska, op. cit., s. 65.

17 Ibidem, s. 65-66.

18 Ibidem, s. 67-70, dotyczy to także np. zaproszenia na obiad.

19 Projekt ustawy z 1985 uchwalony 13 września 1988 r. wszedł w życie we wrześniu 1989 r. zob. szerzej K. Keyes, Lobbying w Kanadzie, opublikowano w: „Materiały i Dokumenty" nr 123, Biuro Studiów i Ekspertyz, Kancelaria Sejmu, kwiecień 1993 oraz na stronach http://www.lobby.biz.pl, tekst ustawy tamże. 
rejestracji są łagodniejsze. Podobne rozwiązania wprowadzono także w Australiii ${ }^{20}$.

Na poziomie struktur Unii Europejskiej nie ustanowiono rozwiązań sui generis poświęconych tej problematyce. W doktrynie jednak podkreśla się, że w rozwoju Unii Europejskiej trudno jest przecenić rolę lobbyingu. Niektórzy autorzy stawiają nawet tezę, że to właśnie grupy nacisku współtworzyły Wspólnoty Europejskie ${ }^{21}$. W 1989 r. Allman Metten zgłosił w Komisji możliwość opracowania projektu kodeksu postępowania grup nacisku. Stanowisko to jednak nie zostało przyjęte. Dwa lata później Marc Galle przygotował na zlecenie Parlamentu raport w tej kwestii, sugerując stosowane rozwiązania i regulacje $\mathrm{e}^{22}$. Jednak i tym razem propozycje nie były do zaakceptowania. Wywołało to jednak reakcję Komisji Europejskiej, która wydała w 1992 r. dokument ,An Open and Structural Dialogue Between Commission and Special Interest Group". Z lektury tego dokumentu wynika, że Komisja uznaje fakt istnienia lobbyingu, choć dostrzega pewne niebezpieczeństwa związane chociażby z takimi zjawiskami jak rozpowszechnianie fałszywych informacji o pracach organów Unii. Aby jednak przeciwdziałać takim negatywnym zjawiskom, zdecydowano się jedynie na apelowanie do środowisk stosujących metody lobbyingowe, aby one same przyjęły reguły samoograniczające, które oparte byłyby na następujących fundamentalnych zasadach: zakazie posługiwania się jakimkolwiek oznaczeniem, tytułem czy znakiem, który wprowadzałby w błąd co do tożsamości; lobbyści powinni kierować się uczciwością i kompetencją, nie powinni rozpowszechniać informacji mogących wprowadzić w błąd odbiorców ${ }^{23}$. W kolejnych latach przygotowywano w strukturach unijnych następne raporty na ten temat ${ }^{24}$. Parlament Europejski uchwalił kodeks postępowania lobbystów w 1997 r., jednak w zna-

20 Lobbying w Australii, opublikowano w: „Materiały i Dokumenty” nr 123, Biuro Studiów i Ekspertyz, Kancelaria Sejmu, kwiecień 1993 oraz na stronach http://www.lobby.biz.pl.

21 J. Rideau, Les grupes d interet dans le systeme institutionel communautaire, „Revue des Affaires Europeennes” 1993, nr 3, s. 1 cyt. za: K. Tarnawska, Rozwój lobbyingu w Unii Europejskiej, „Sprawy Międzynarodowe” 1999, nr 3, s. 25.

${ }^{22}$ K. Jasiecki, M. Molęda-Zdziech, U. Kurczewska, op. cit., s. 76 także cytowany tamże J. Greenwood, Representing Interest in the European Union, New York 1997, s. 90 .

23 Ibidem, s. 77.

24 Przywołać tu należy przede wszystkim raport Glyna Forda i Jeana - Thomasa Nordmanna. 
cznie okrojonej wersji. Przyjęto bowiem jedynie obowiązek ujawnienia swojej działalności, powstrzymanie się od wszelkich działań nieuczciwych oraz honorowanie zakazu wręczenia jakichkolwiek korzyści majątkowych parlamentarzystom ${ }^{25}$. Parlamentarzyści muszą zarejestrować każdy prezent przewyższający wartością 600 Euro, a nadto składać szczegółowe sprawozdania na temat aktywności zawodowej ${ }^{26}$. W zamian przyjęto rozwiązania pozwalające na wydawanie na wniosek deputowanego lub określonej grupy deputowanych wejściówek uprawniających do wstępu na spotkania różnych gremiów i organów Parlamentu. Z kolei w Traktacie z Maastricht w art. 245 ust. 2 i 229 ust. 2 zobowiązano Komisję Europejską do utrzymywania kontaktów z grupami interesu, w tym także międzynarodowymi ${ }^{27}$.

W większości państw europejskich funkcjonują podobne rozwiązania. Wynikają one albo z przyjętych zwyczajów, albo regulacji określających działalność i procedury parlamentarne (regulaminy). W żadnym bowiem z krajów Unii Europejskiej nie ma odrębnej ustawy na ten temat. W Belgii, Grecji, Hiszpanii, Irlandii brak jest nawet jakichkolwiek regulacji. Choć trudno zaprzeczyć, że zjawisko lobbyingu jest tam nieznane. Co więcej, w parlamentach działają nieformalne grupy ${ }^{28}$.

W Danii regulacje prawne odnoszą się do działalności lobbystów w Folketingu, bowiem istnieje obowiązek rejestracji lobbystów działających w poszczególnych komisjach. Na posiedzeniach komisji przedstawiciele komisji nie mogą negocjować z lobbystami, a jedynie zapoznać się ze stanowiskiem tych podmiotów ${ }^{29}$.

We Francji nie ma również odrębnej regulacji przewidującej rejestr lobbystów. Jednakże przedstawiciele grup nacisku (interesu) mogą zwrócić się z wnioskiem o prawo wstępu na posiedzenie organów Senatu lub Zgromadzenia Narodowego. Niektóre organizacje społeczne lub zawodowe oraz przedsiębiorstwa o szczególnym znaczeniu, takie jak: przedstawiciele samorządu adwokackiego, notarialnego, izb rolniczych, Gaz de

25 K. Tarnawska, op. cit., s.. 39.

26 K. Jasiecki, M. Molęda-Zdziech, U. Kurczewska, op. cit., s.78.

27 U. Kurczewska, M. Molęda-Zdziech, Lobbing w Unii Europejskiej, Warszawa 2002, s. 24.

${ }^{28}$ Lobbying $w$ krajach Unii Europejskiej, opublikowano w: „Materiały i Dokumenty" nr 123, Biuro Studiów i Ekspertyz, Kancelaria Sejmu, kwiecień 1995 oraz na stronach http://www.lobby.biz.pl.

29 Ibidem. 
France, mają stałe wejściówki. Na podstawie regulaminu Senatu lub Zgromadzenia Narodowego możliwe jest organizowanie grup badawczych i grup roboczych skupiających senatorów jednej lub kilku komisji, choć z drugiej strony zabrania się wyraźnie tworzenia tam grup w celu obrony interesów prywatnych, lokalnych lub zawodowych, a także wykorzystywania mandatu członkom Zgromadzenia Narodowego do popierania konkretnych inicjatyw pochodzących od stowarzyszeń, związków zawodowych, izb gospodarczych itp. ${ }^{30}$

We Włoszech brak jest także odrębnych regulacji, choć przygotowano już kilka projektów ustaw, które ciągle są przedmiotem prac legislacyjnych $^{31}$.

W Luksemburgu także nie ma szczególnych regulacji, tym niemniej gwarantuje się komisjom parlamentarnym lub posłom prawo zapoznania się ze stanowiskiem poszczególnych grup nacisku. Podobne rozwiązania proponuje się w Holandii, Austrii, Portugalii i Finlandii. W Szwecji dzisiaj nie ma ustawy o działalności lobbyingowej, choć w 1995 r. powstały dwa projekty ustaw dotyczących lobbyingu. Projekty te zakładają ujawnienie kogo lobbysta reprezentuje oraz zakaz wobec osób pełniących funkcje publiczne angażowania się w działalność lobbyingową ${ }^{32}$.

$\mathrm{Na}$ tle przedstawionych powyżej krajów Unii Europejskiej Wielka Brytania przedstawia się szczególnie. Bo choć także tu nie ma szczególnych regulacji, to jednak zwyczaje konstytucyjne i obyczaje polityczne oraz zasady kultury politycznej wymuszają określony kanon postępowania. Każdemu obywatelowi gwarantuje się prawo działania jako lobbysta, czyli wpływania na członków Parlamentu. Istnieje jednakże stowarzyszenie doradców public relations, do którego przynależność jest dobrowolna, jednak powszechna. Członkowie tego stowarzyszenia przyjęli kodeks etyki lobbystów, który nakazuje ujawnić najważniejsze informacje związane z określoną strategią lobbyingową. Ponadto regulaminy Izby Gmin i Lordów wymagają rejestracji pośredników parlamentarnych. Dodatkowo członkowie Parlamentu, którzy zamierzają podjąć działalność lobbyin-

30 Ibidem, patrz także K. Jasiecki, M. Molęda-Zdziech, U. Kurczewska, op. cit., s.71-73; zob. także P. Andrzejewski, P. Deszczyński, K. Gołata, M. Szczepaniak, Europejskie systemy polityczne, Poznań 1996, s. 61-64.

${ }_{31}$ Lobbying $w$ krajach Unii Europejskiej, opublikowano w: ,Materiały i Dokumenty" nr 123, Biuro Studiów i Ekspertyz, Kancelaria Sejmu, kwiecień 1995 oraz na stronach http://www.lobby.biz.pl.

32 Ibidem. 
gową, zobowiązani są ujawnić ewentualne honorarium uzyskane $\mathrm{z}$ takich tytułów. Jest to jednak bardziej sprawa honoru niż wymogów prawnych ${ }^{33}$. Z kolei członkowie Izby Lordów sami składają oświadczenia określające ich dochody i wydatki, a nadto informują o przypadkach brania udziału w dyskusji, w której reprezentowane są określone interesy ${ }^{34}$.

Wreszcie należy tu przywołać rozwiązania niemieckie obowiązujące od 1972 r. Wówczas Bundestag przyjął obowiązek rejestracji lobbystów. $\mathrm{Na}$ tej podstawie publikuje się listy podmiotów, które działają na rzecz konkretnej inicjatywy politycznej w Bundestagu. Listy te są publikowane w powszechnie dostępnych periodykach. Co jednak istotne, członkowie Bundestagu sami mogą wcielać się w rolę lobbystów. Fakt ten podlega jednak ujawnieniu. Wprowadzono limity dochodów, jakie mogą $\mathrm{z}$ tego tytułu uzyskać parlamentarzyści ${ }^{35}$.

W Polsce o potrzebie ustawowego uregulowania działalności lobbyingowej mówiło się głośno zwłaszcza po upublicznieniu nieprawidłowości związanych z działalnością grup interesu, jak chociażby po tzw. aferze Grabka. W dniu 7 listopada 1995 w Senacie zorganizowano dyskusję „Sens, istota i granice lobbingu”36. Następnie w kręgach Unii Wolności przygotowano projekt ustawy o jawności procedur decyzyjnych, grupach interesów i publicznym dostępie do informacji ${ }^{37}$. Materię tę rozwijano podczas dyskusji na konferencji zatytułowanej „Jawność procesów decyzyjnych w Polsce - dialog, lobbying, informacja” odbywającej się w Warszawie 16 lutego 1999 r. ${ }^{38}$ I choć projekt ten nie doczekał się kształtu normatywnego, zasługuje na uwagę z kilku powodów. Przede wszystkim dlatego, że sformułowano tu definicję takich pojęć jak grupa interesów,

33 Ibidem.

34 K. Jasiecki, M. Molęda-Zdziech, U. Kurczewska, op. cit., s.73.

35 Ibidem, s. 70-71.

36 Ibidem.

37 A. Kaczorowski, M. Jakubowski, Lobbying - założenia do ustawy, Warszawa 1998.

38 Patrz szerzej wystapienia: A. Kaczorowski, M. Jakubowski, Lobbying a dostęp do informacji-założenia regulacji prawnych, Warszawa 1999; K. Jasiecki, Doświadczenia lobbyingu na świecie-implikacje dla Polski, Warszawa 1999, a także Stanowisko Instytutu Lecha Wałęsy odnośnie problematyki lobbyingu. T. Kozłowski, Samorzadowy lobbying a kohabitacja rzqdu i Samorzqdu terytorialnego, Warszawa 1999. Patrz także: M. Starkowska, Wykorzystanie mediów w lobbyingu, Warszawa 1999; W. Kisiel, Miejsce lobbyingu i kohabitacji wśród metod działania samorzqdu terytorialnego, Warszawa 1999. 
a zwłaszcza działalność lobbyingowa. Zatem pod pojęciem grupy interesów projekt ten rozumiał organizację i jednostki organizacyjne powstałe i działające na podstawie przepisów prawa, które w zakresie swego przedmiotu działalności reprezentują społeczne, ekonomiczne, naukowe, kulturalne interesy własne, swoich członków lub osób, które powierzyły im reprezentowanie takich interesów. Z kolei pod pojęciem działalności lobbyingowej projekt rozumiał każde działanie, którego celem jest, w ramach obowiązującego prawa, wywarcie wpływu na organy władzy i administracji - swojej lub wyrażonej przez grupę interesów, w szczególności w zakresie stanowienia prawa, kształtowania polityki państwa, przyjmowania planów lub programów strategicznych, w tym lokalnych, rozstrzygania sporów, z wyłączeniem sporów rozstrzyganych przez organy wymiaru sprawiedliwości, mianowania na stanowiska, przyznawania szczególnych uprawnień, zawierania umów, gwarantowania kredytów, wydawania innych decyzji administracyjnych. Projekt wprowadzał określone zasady działalności lobbyingowej. Zgodnie z tymi założeniami działalność lobbyingowa mogłaby być prowadzona bez obowiązku rejestracji. Mogłaby odbywać się ona tylko z uwzględnieniem przepisów dotyczących form prawnych prowadzenia działalności gospodarczej. Wszystkie korzyści z działalności lobbyingowej podlegałyby opodatkowaniu, organy władzy i administracji publicznej byłyby zobowiązane do podawania do publicznej wiadomości informacji o przygotowanych projektach aktów normatywnych, ich uzasadnieniach oraz autorach i osobach odpowiadających za dany projekt, a także informacji o grupach interesów, które brały udziały w konsultacjach przygotowujących taki projekt.

Projekt zakładał także szczególną procedurę konsultowania projektów aktów normatywnych. Przewidziano tu możliwość zgłaszania przez grupy interesów swoich propozycji i komentarzy, które powinny być umieszczane na internetowych stronach z samym projektem. Ponadto grupa interesu mogłaby żądać, aby organ władzy zajął określone stanowisko wobec opinii przygotowanej przez grupę nacisku.

Z kolei w 2003 r. w Ministerstwie Spraw Wewnętrznych i Administracji przygotowano projekt ustawy o działalności lobbingowej ${ }^{39}$. W uzasadnieniu tego dokumentu stwierdzono, że ,problematyka lobbingu jest niezwykle ważnym i niezbędnym elementem tworzenia polityki gospodarczej

39 Projekt został opatrzony datą 11 marca 2003 r. Na marginesie warto podkreślić pisownię i odesłać do przypisu, w którym wyjaśniono kwestię pisowni tego terminu. 
i społecznej”. Jak wyjawiono, „,bodźcem do uregulowania materii lobbingowej jest obserwowana praktyka wykonywania tego typu działalności przy jednoczesnym braku jakichkolwiek uregulowań prawnych określających dopuszczalne formy i metody lobbingu rozumianego jako wywieranie wpływu na przedstawicieli władz ustawodawczych i wykonawczych w celu osiagnięcia określonych celów zgodnych z własnymi - szeroko pojętymi - interesami” ${ }^{40}$. Ponadto zdaniem autorów tego projektu, taka regulacja wpisuje się w nurt zapoczątkowany przez ustawę z dnia 6 września 2001 r. o dostępie do informacji publicznej, a mianowicie przejrzystości działania organów władzy publicznej i życia publicznego.

Zakres przedmiotowy projektowanego aktu normatywnego ustala, iż w tej drodze reguluje się zasady wykonywania działalności lobbyingowej, dopuszczalne formy oddziaływania na rozstrzygnięcia organów władzy publicznej, formy kontroli działalności lobbyingowej, a także sankcje za wykonywanie tej działalności z naruszeniem przepisów ustawy. Jako niezwykle istotną należy ocenić próbę zdefiniowania pojęcia lobbyingu. W rozumieniu tego projektu lobbyingiem jest każde działanie prowadzone metodami prawnie dozwolonymi, realizowane w formach określonych wyłącznie w tej ustawie, zmierzające do wywarcia wpływu na organy władzy publicznej w celu uwzględnienia w podejmowanych rozstrzygnięciach racji i interesów określonych grup społecznych lub zawodowych albo podmiotów indywidualnych. Chodzi tu o decyzje podejmowane w takich sprawach, jak stanowienie prawa, kształtowanie polityki państwa na szczeblu centralnym i lokalnym, przyznawanie przez organy władzy publicznej przywilejów w formie koncesji, zezwoleń, licencji, ulg, umorzeń obciążeń, ograniczenia lub zwolnienia z obowiązków publicznoprawnych, gwarancji, poręczeń, dotacji, kontyngentów, wydawania innych decyzji administracyjnych, zawierania umów, których stroną jest organ władzy publicznej. Warty podkreślenia jest fakt, że ustawa odnosiłaby się zarówno do lobbingu na płaszczyźnie centralnej, jak i lokalnej.

Jednocześnie projekt ustawy przewiduje określone wyłączenia. I tak zgodnie z art. 2 dokumentu, ustawa nie będzie naruszać prawa obywateli do składania petycji, wniosków i skarg do organów władzy publicznej. Chodzi tu o gwarantowane w art. 63 Konstytucji Rzeczypospolitej Polskiej prawo składania w interesie publicznym, własnym lub innej osoby i za jej zgodą petycji, skarg i wniosków do organów państwowych, orga-

40 Tak w uzasadnieniu projektu ustawy. 
nów jednostek samorządu terytorialnego, organów samorządowych jednostek organizacyjnych oraz do organizacji i instytucji społecznych w związku z wykonywanymi przez nie zadaniami zleconymi z zakresu administracji publicznych ${ }^{41}$. Prawo to zostało także potwierdzone i skonkretyzowane w art. 221 i następnych kodeksu postępowania administracyjnego. Należy w tym miejscu podkreślić, że w myśl art. 225 nikt nie może być narażony na jakikolwiek uszczerbek lub zarzut z powodu złożenia skargi lub wniosku albo z powodu dostarczenia materiału do publikacji o znamionach skargi lub wniosku, jeżeli działał w granicach prawem dozwolonych.

Z kolei zgodnie z ust. 2 art. 5 projektu ustawy, nie stanowi działalności lobbingowej występowanie przed organami władzy publicznej w indywidualnej, własnej sprawie z zakresu administracji publicznej albo w charakterze pełnomocnika strony w takiej sprawie, a także działalność publiczna realizowana przez statutowe organy partii politycznych. W tym przepisie mamy dwa zupełnie różnego rodzaju wyłączenia. Pierwszy z nich związany jest $\mathrm{z}$ występowaniem $\mathrm{w}$ charakterze strony $\mathrm{w}$ postępowaniu administracyjnym. Takie wyłączenie jest niezbędne, bowiem w przeciwnym razie, każdy uczestnik takiego postępowania (np. o wydanie pozwolenia na budowę, o rozpatrzenie odwołania od decyzji Urzędu Skarbowego) musiałby zarejestrować się jako lobbysta, co byłoby oczywistym nonsensem. Tym niemniej na tle tak ukształtowanych wyłączeń można mieć wątpliwości czy np. obywatel może, bez konieczności zarejestrowania się jako lobbysta, spotkać się z posłem czy senatorem z własnego okręgu wyborczego, aby zgodnie z art. 21 ustawy o wykonywaniu mandatu posła i senatora przekazać opinie, postulaty, wnioski wyborców oraz ich organizacji, co parlamentarzyści powinni brać pod uwagę w swej działalności sejmowej i senackiej. Tym bardziej, że zgodnie z ust. 2 tego przepisu poseł lub senator nie może być zobowiązany do ujawnienia informacji o osobie, która przekazała mu określone informacje lub przedstawiła opinię, bowiem art. 163 kodeksu postępowania karnego nie stosuje się w tym przypadku. Druga grupa wyłączeń dotyczy działalności statutowej partii politycznej. I jest to w zasadzie do zaakceptowania, choć wydaje się, że ta możliwość może stać się doskonałą okazją do obejścia pozostałych obowiązków wynikających z projektowanego aktu normatywnego, tym bar-

41 W. Skrzydło, Konstytucja Rzeczypospolitej Polskiej. Komentarz, Zakamycze 2000, s. 75 . 
dziej, gdy zważy się, ile partii politycznych jest wpisanych do ewidencji działalności partii politycznych i jak stosunkowo łatwo założyć nowe stronnictwo polityczne.

Kolejne wyłączenie zamieszczono w ust. 2 art. 2, zgodnie z którym ustawa nie narusza przepisów innych ustaw określających uprawnienia grup społecznych lub zawodowych, w szczególności zorganizowanych $\mathrm{w}$ formie organizacji pracodawców lub organizacji pracobiorców, do współuczestniczenia w kształtowaniu polityki państwa dotyczącej ich statutowego przedmiotu działania oraz obowiązków organów władzy publicznej w tym zakresie, a także zasady dostępu do informacji publicznej. W przypadku organizacji pracodawców i związków zawodowych, chodzi tu z pewnością o uprawnienia zapewnione w ustawie z 23 maja $1991 \mathrm{r}$. o związkach zawodowych. W myśl art. 19 tego aktu normatywnego ogólnokrajowa organizacja międzyzwiązkowa, a także ogólnokrajowy związek zawodowy reprezentatywny dla pracowników większości zakładów pracy, mają prawo opiniowania założeń i projektów ustaw oraz aktów wykonawczych do tych ustaw w zakresie objętym zadaniami związków zawodowych. W takich przypadkach organy władzy i administracji państwowej oraz organy samorządu terytorialnego są zobowiązane skierować założenia albo projekty wyżej wymienionych aktów prawnych do odpowiednich władz statutowych związku, określając termin przedstawienia opinii, nie krótszy jednak niż 30 dni. W razie odrzucenia w całości lub w części stanowiska związku, właściwy organ administracji państwowej lub samorządu terytorialnego informuje o tym związek na piśmie, podając uzasadnienie swojego stanowiska. W razie rozbieżności stanowisk związek może przedstawić swoją opinię na posiedzeniu właściwej komisji sejmowej, senackiej lub samorządu terytorialnego. Ponadto związkom zawodowym przysługuje prawo wyrażania publicznie opinii na temat założeń lub projektów $\mathrm{w}$ środkach masowego przekazu, $\mathrm{w}$ tym także $\mathrm{w}$ radio i telewizji. Trzeba także pamiętać, że zgodnie z art. 20 tej ustawy, wyżej wskazane podmioty mają prawo występowania $\mathrm{z}$ wnioskami o wydanie lub zmianę ustawy albo innego aktu prawnego w zakresie spraw objętych zadaniami związku zawodowego. Wnioski dotyczące ustaw związek kieruje do posłów lub organów mających prawo inicjatywy ustawodawczej. W przypadku aktów prawnych niższego rzędu, wnioski kieruje się do organów uprawnionych do ich wydania. Organ państwowy, do którego został skierowany wniosek, obowiązany jest w terminie $30 \mathrm{dni}$ przedstawić związkowi zawodowemu swoje stanowisko, a w razie negatywnego stanowiska - także jego uzasadnienie. Podobne uprawnienia za- 
gwarantowano w art. 16 ustawy z 23 maja 1991 r. o organizacjach pracodawców.

Kolejnym wyłączeniem podmiotowym jest wyłączenie stosowania ustawy do członków misji dyplomatycznych i urzędów konsularnych działających na terytorium Rzeczypospolitej Polskiej, przedstawicieli organizacji międzynarodowych, którzy występują w charakterze ekspertów wobec organów władzy publicznej RP oraz do organizacji pozarządowych, które uzyskały status organizacji pożytku publicznego. O ile w pierwszym przypadku nie ma wątpliwości co do zasadności takiego wyłączenia, o tyle w przypadku ekspertów takie wątpliwości pojawiają się. Bowiem jeżeli sobie uświadomimy, że składanie różnego rodzaju opinii jest chyba najczęściej stosowną techniką w lobbyingu w USA, to należałoby zapytać czy nie jest to wyłączenie, które w istocie spowoduje, że ta ustawa będzie miała tylko ograniczone zastosowanie, bo pomija całkowicie lobbying zagraniczny. Należałoby zatem postulować, aby stosowny zapis brzmiał, iż to wyłączenie stosuje się do ekspertów, którzy przygotowali stosowne opinie na zlecenie organów władzy publicznej lub podmiotów prawa międzynarodowego publicznego. Natomiast dzisiaj nie ma żadnej regulacji prawnej dotyczącej organizacji pozarządowych, które uzyskały status organizacji pożytku publicznego. Obecnie jednak trwają prace nad taką ustawą. Wydaje się jednak, że nawet po wprowadzeniu takiej kategorii prawnej do systemu prawnego, takie wyłączenie podmiotowe będzie nieuzasadnione z powodów, o których mowa była już wcześniej. Autorzy tego projektu tłumaczą, iż przyświecała im chęć wyeliminowania obaw, iż projektowana ustawa ograniczyłaby rozwój i aktywność tych form aktywności społecznej. W takim założeniu widać pewną niekonsekwencję. Bowiem jeżeli zgodnie z wolą projektodawców ustawa ma służyć jedynie ujawnieniu pewnych mechanizmów wywierania wpływu, to o żadnym niebezpieczeństwie ubezwłasnowolnia tych organizacji chyba nie może być mowy.

Jak zdradzają projektodawcy w uzasadnieniu, dokument ten był konsultowany m.in. $z$ takimi organizacjami jak: Business Centre Club, Polska Konfederacja Pracodawców Prywatnych, a także z NSZZ „Solidarność” i OPZZ. Organizacje te proponowały własne pomysły niektórych rozwiązań prawnych. I tak przykładowo odnośnie omawianego w tym miejscu zagadnienia postulowano, aby wyłączenie obejmowało także organizacje pracodawców, mając na uwadze ich rolę w Trójstronnej Komisji do Spraw Społeczno-Gospodarczych. Należy się jednak zgodzić z autorami projektu, że takie wyłączenie nie byłoby celowe, a w kwestii udziału orga- 
nizacji pracodawców w pracach takiego ciała to wyłączenie zamieszczone $\mathrm{w}$ art. 2 ust. 2 jest w tym zakresie zupełnie wystarczające.

Natomiast zupełnie zrozumiałym i bezspornym jest wyłączenie zawarte $\mathrm{w}$ art. 6 projektu, zgodnie z którym działalność lobbingowa nie może być realizowana przed organami władzy publicznej sprawującymi wymiar sprawiedliwości.

Rozdział drugi projektowanego aktu określa zasady wykonywania działalności lobbingowej. Zgodnie z art. 7, działalność lobbingowa mogłaby być wykonywana poprzez:

a) organizowanie lub uczestniczenie w spotkaniach $z$ osobami pełniącymi funkcje publiczne ${ }^{42}, \mathrm{z}$ pracownikami urzędów sprawujących obsługę organów władzy publicznej, a także z posłami i senatorami;

42 Chodzi tu o osoby pełniące funkcje publiczne w rozumieniu przepisów o ograniczeniu prowadzenia działalności gospodarczej. Kwestie te reguluje ustawa $\mathrm{z}$ dnia 21 sierpnia 1997 r. o ograniczeniu prowadzenia działalności gospodarczej przez osoby pełniące funkcje publiczne (Dz. U. 1997, Nr 106, poz. 679 z późn. zm.). Zgodnie $\mathrm{z}$ art. 2 dotyczy to następujących urzędników:

1) pracowników urzędów państwowych, w tym członków korpusu służby cywilnej, zajmujących stanowiska kierownicze:

a) dyrektora generalnego, dyrektora departamentu (jednostki równorzędnej) i jego zastępcy oraz naczelnika wydziału (jednostki równorzędnej) - w urzędach naczelnych i centralnych organów państwowych,

b) dyrektora generalnego urzędu wojewódzkiego, dyrektora wydziału (jednostki równorzędnej) i jego zastępcy oraz głównego księgowego, kierownika urzędu rejonowego i jego zastępcy oraz głównego księgowego - w urzędach terenowych organów rządowej administracji ogólnej,

c) kierownika urzędu i jego zastępcy - w urzędach terenowych organów rządowej administracji specjalnej,

2) pracowników urzędów państwowych, w tym członków korpusu służby cywilnej, zajmujących stanowiska równorzędne pod względem płacowym ze stanowiskami wymienionymi w pkt. 1 ,

3) dyrektora generalnego Najwyższej Izby Kontroli oraz pracowników Najwyższej Izby Kontroli nadzorujących lub wykonujących czynności kontrolne,

4) pracowników regionalnych izb obrachunkowych zajmujących stanowiska: prezesa, członka kolegium, naczelnika wydziału oraz inspektora do spraw kontroli,

5) pracowników samorządowych kolegiów odwoławczych zajmujących stanowiska: przewodniczącego, jego zastępcy oraz etatowego członka kolegium,

6) wójtów (burmistrzów, prezydentów miast), zastępców wójtów (burmistrzów, prezydentów miast), skarbników gmin, sekretarzy gmin, kierowników jednostek organizacyjnych gminy, osoby zarządzające i członków organów zarządzających gminnymi osobami prawnymi oraz inne osoby wydające decyzje administracyjne w imieniu wójta (burmistrza, prezydenta miasta), 
b) przedstawianie właściwym organom projektów aktów normatywnych oraz projektów innych dokumentów, w tym o charakterze technicznym, w celu podjęcia ewentualnych inicjatyw legislacyjnych lub zobowiązania w inny sposób do ich stosowania;

c) zgłaszanie propozycji lub wniosków o wydanie określonych rozstrzygnięć, w tym nakłanianie do ich podjęcia;

d) przedstawianie raportów i ekspertyz zawierających szczegółowe propozycje rozwiązań, wyrażania opinii wobec przygotowanych przez organy władzy publicznej rozstrzygnięć lub aktów prawnych.

Ustawa wyraźnie zezwala zarówno na lobbying na rzecz własnych grup nacisku, jak również $\mathrm{w}$ formie działalności profesjonalnej poprzez

7) członków zarządów powiatów, skarbników powiatów, sekretarzy powiatów, kierowników jednostek organizacyjnych powiatu, osoby zarządzające i członków organów zarządzających powiatowymi osobami prawnymi oraz inne osoby wydające decyzje administracyjne w imieniu starosty,

8) członków zarządów województw, skarbników województw, kierowników wojewódzkich samorządowych jednostek organizacyjnych, osoby zarządzające i członków organów zarządzających wojewódzkimi osobami prawnymi oraz inne osoby wydające decyzje administracyjne w imieniu marszałka województwa,

9) pracowników banków państwowych zajmujących stanowiska: prezesa, wiceprezesa, członka zarządu oraz skarbnika,

10) pracowników przedsiębiorstw państwowych zajmujących stanowiska: dyrektora przedsiębiorstwa, jego zastępcy oraz głównego księgowego,

11) pracowników jednoosobowych spółek Skarbu Państwa oraz spółek, w których udział Skarbu Państwa przekracza 50\% kapitału zakładowego lub 50\% liczby akcji, zajmujących stanowiska: prezesa, wiceprezesa i członka zarządu,

12) pracowników agencji państwowych zajmujących stanowiska: prezesa, wiceprezesa, dyrektora zespołu, dyrektora oddziału terenowego i jego zastępcy - lub stanowiska równorzędne,

13) inne osoby pełniące funkcje publiczne, jeżeli ustawa szczególna tak stanowi. Dotyczy to w szczególności: Prezydenta Rzeczypospolitej Polskiej, Marszałka Sejmu, Marszałka Senatu, Prezesa Rady Ministrów, Szefa Kancelarii Prezydenta, Szefa Kancelarii Sejmu, Szefa Kancelarii Senatu, Prezesa Trybunału Konstytucyjnego, Prezesa Najwyższej Izby Kontroli, Rzecznika Praw Obywatelskich, Prezesa Naczelnego Sądu Administracyjnego, Prezesa Narodowego Banku Polskiego, Przewodniczącego Krajowej Rady Radiofonii i Telewizji, Głównego Inspektora Pracy, Prezesa Polskiej Akademii Nauk, Kierownika Krajowego Biura Wyborczego oraz Rzecznika Ubezpieczonych, Pierwszego Prezesa Sądu Najwyższego, a także sędziów, prokuratorów, radnych, pracowników regionalnych izb obrachunkowych zajmujących stanowiska prezesa, członka kolegium, naczelnika wydziału oraz inspektora do spraw kontroli, posłów i senatorów, urzędników służby cywilnej. 
reprezentowanie innych podmiotów. W art. 8 wskazuje się, że działalność lobbyingowa może być wykonywana w związku z członkostwem w organizacji, na podstawie stosunku pracy, w formie działalności gospodarczej, na podstawie umowy cywilnoprawnej. Idea ta zostaje rozwinięta w art. 9 i 10. Zgodnie z art. 9 bowiem działalność lobbyingowa może być realizowana $\mathrm{w}$ celu promowania lub obrony własnych interesów podmiotu lub członków tej organizacji albo zgodnie z art. $10 \mathrm{w}$ celu osiagnięcia zysku poprzez świadczenia na podstawie umowy usług, których przedmiotem jest reprezentowanie przed organami władzy publicznej interesów powierzonych przez inne podmioty. W ust. 2 tego przepisu expressis verbis zezwala się na wykonywanie zadań zleconych przez podmioty nie posiadające w RP miejsca zamieszkania lub siedziby oraz na rzecz cudzoziemców.

Jednak najważniejszym rozwiązaniem zawartym w tej ustawie jest wprowadzenie form kontroli działalności lobbyingowej. Jednym z takich instrumentów jest rejestr podmiotów wykonujących działalność lobbyingową. Przede wszystkim wprowadza się tu obowiązek zgłoszenia do tego jawnego rejestru wszystkich podmiotów, o których mowa była powyżej, a które zamierzają wykonywać działalność lobbyingową. Zgodnie z projektem, rejestr lobbystów w formie elektronicznej dostępnej w Internecie prowadziłby minister właściwy do spraw administracji publicznej, czyli obecnie Minister Spraw Wewnętrznych i Administracji. Wydaje się, że rozwiązanie to wzbudza najwięcej emocji. Wskazuje się bowiem, że jest to rozwiązanie bez precedensu, a poza tym podnosi się, że prowadzenie rejestru należałoby do kompetencji Ministra, który jest zwierzchnikiem Policji oraz Agencji Bezpieczeństwa Wewnętrznego. Być może lepszym rozwiązaniem byłoby przekazanie tego uprawnienia do kompetencji Marszałka Sejmu.

Projekt ustawy nakazuje podanie następujących danych do rejestru:

1) imię i nazwisko, adres zamieszkania osoby fizycznej będącej członkiem lub pracownikiem podmiotu, który podejmuje określoną inicjatywę lobbyingową, względnie dane przedsiębiorcy, który wykonuje zadania zlecone, a także numer rejestru Krajowego Rejestru Sądowego, pod którym jest wpisany,

2) ujawnienie podmiotów, na rzecz których prowadzona jest działalność lobbyingowa,

3) zdefiniowanie dziedzin, w których zamierza się wywierać wpływ.

Obowiązek zgłoszenia powyższych informacji spoczywa, w myśl rozwiązań przewidywanych w komentowanym tu projekcie, na podmiocie 
podejmującym działalność lobbyingową. Przy czym zakreślono tu termin 14 dni na przekazanie informacji do rejestru o fakcie zarejestrowania działalności gospodarczej polegającej na świadczeniu usług lobbyingowych albo powierzenia pracownikowi lub członkowi obowiązków w tym zakresie, lub zawarcia umowy cywilnoprawnej, której treścią jest zobowiązanie do wykonania działalności lobbyingowej. Z przepisu tego wynika, że termin 14-dniowy dotyczyłby tylko wypadków rozpoczęcia działalności lobbyingowej. Bowiem wszelkie zmiany dotyczące informacji podlegających wpisowi do rejestru należałoby zgłaszać w ciagu 7 dni od momentu ich wystąpienia. Stąd też rodzić mogą się liczne wątpliwości. Chociażby, jak należy potraktować sytuację, gdy pracodawca kieruje do zadań lobbyingowych kolejnego swojego pracownika albo zwalnia z tego obowiązku dotychczasowego i powierza te zadania komuś innemu. Podobne trudności z wykładnią pojawić mogą się, gdy podmiot wykonujący działalność lobbyingową na podstawie umowy cywilnoprawnej przyjmuje kolejne zlecenie. Wydaje się, że dla uproszczenia sytuacji należałoby po prostu wprowadzić jednolity termin dla obu przypadków. Jednocześnie w projekcie ustawy zamieszczono delegację ustawową dla Ministra Spraw Wewnętrznych i Administracji do wydania rozporządzenia szczegółowo określającego sposób prowadzenia rejestru, proponującego formularze zgłoszeniowe oraz rodzaje dokumentów będących podstawą dokonania stosownych wpisów, a także tryb udostępniania informacji zawartych $\mathrm{w}$ rejestrze.

$\mathrm{W}$ art. 13 wprowadzano zasadę, że stanowisko podmiotu wykonującego działalność lobbyingową należy traktować wyłącznie jako opinię w danej sprawie i nie może być ona wyłączną przesłanką do podjęcia rozstrzygnięcia w określonej materii. Rozwiązanie to może budzić pewne zastrzeżenia. Pojawia się bowiem wątpliwość czy treść art. 13 oznacza, że konieczne jest zgromadzenie kilku stanowisk różnych grup nacisku, czy też, że wystarcza stanowisko chociażby jednej organizacji, ale konieczne jest wykazanie w procesie decyzyjnym brania pod uwagę innych elementów.

Innym mechanizmem pozwalającym na zapewnienie kontroli działalności lobbyingowej jest wpisanie do projektu ustawy obowiązku ciążącego na pracownikach urzędów obsługujących organy władzy publicznej, odnotowywania w aktach prowadzonych spraw przypadki nawiązywania z nimi kontaktów przez osoby, których działania lub zachowania wskazują na prowadzenie działalności lobbyingowej. Ponadto zobligowano te osoby do poinformowania swoich przełożonych o propozycjach udziału 
w spotkaniach z lobbystami. W przypadku niedopełnienia powyższych obowiązków grozić miałyby sankcje służbowe. Szczegółowe kwestie techniczne dotyczące dokumentowania podejmowanych kontaktów mieliby uregulować kierownicy urzędów obsługujących organy władzy publicznej. Natomiast w kolejnej delegacji ustawowej znalazło się upoważnienie dla Ministra Spraw Wewnętrznych i Administracji do wydania rozporządzenia określającego warunki dostępu zarejestrowanych lobbystów do urzędów administracji rządowej i samorządowej oraz szczególny tryb realizacji tych uprawnień. Wydaje się jednak, że powyższa materia jest materią ustawową i że kwestie te powinny znaleźć się w komentowanym akcie normatywnym, a nie w akcie wykonawczym.

W art. 15 projektu ustawy znalazło się zobowiązanie ciążące na organach władzy publicznej do zamieszczania w Biuletynie Informacji Publicznej ${ }^{43}$ informacji o zadeklarowanym przez lobbystów zainteresowaniu określonym rozstrzygnięciem, wraz ze wskazaniem oczekiwanego przez te podmioty rozstrzygnięcia. Natomiast w razie uwzględnienia opinii lobbysty, organ władzy publicznej jest zobowiązany podać informację o tym po raz kolejny w Biuletynie, a nadto wprowadzono obowiązek zamieszczenia tej opinii w uzasadnieniu projektu aktu normatywnego, którego to stanowisko dotyczy.

Kolejny przepis projektu obliguje osoby zajmujące stanowisko : ministra, sekretarza i podsekretarza stanu w ministerstwach, Kancelarii Premiera i Prezydenta, kierowników i zastępców kierowników urzędów centralnych, wojewody oraz jego zastępcy, do informowania właściwych przełożonych o każdym przypadku podjęcia wobec tych osób działalności lobbyingowej. W przypadku naruszenia tego obowiązku przełożony może wyciagnąć konsekwencje służbowe łącznie z odwołaniem ze stanowiska. Podobna reguła dotyczyć miałaby posłów i senatorów, którzy winni informować Marszałka Sejmu lub Senatu, radnych gminnych, powiatowych, sejmiku wojewódzkiego, którzy powinni poinformować przewodniczącego rady gminy, powiatu sejmiku wojewódzkiego, a wreszcie wójta, burmistrza, prezydenta miasta oraz ich zastępców, starosty i wice starosty, marszałka i wicemarszałków województwa, którzy obowiązani są informować o powyższym wojewodę. M.in. na podstawie powyższych relacji

43 Zgodnie z art. 8 ustawy z dnia 6 września 2001 r. o dostępie do informacji publicznej (Dz. U. 2001, Nr 112 poz. 1198) utworzono urzędowy publikator teleinformatyczny zwany Biuletynem Informacji Publicznej - w celu powszechnego udostępniania informacji publicznej, w postaci ujednoliconego systemu stron w sieci teleinformatycznej. 
kierownicy urzędów obsługujących organy władzy publicznej, w oparciu o rozwiązania zawarte $\mathrm{w}$ prezentowanym projekcie, powinni przedstawić i opublikować w Biuletynie Informacji Publicznej coroczne sprawozdanie, najpóźniej do 28 lutego, zawierające dane dotyczące takich kwestii, jak określenie spraw, wobec których podejmowana była działalność lobbyingowa, wskazanie podmiotów, które wykonywały tę działalność, określenie form podjętej działalności z zaznaczeniem, na czym ona polegała, na wspieraniu czy też na występowaniu przeciwko określonym przedsięwzięciom, projektom lub inicjatywom, opisanie zakończenia sprawy z uwzględnieniem ewentualnego wpływu działalności lobbyingowej na jej załatwienie.

Ogromne kontrowersje budzi kształt projektowanego art. 19 ustawy, w myśl którego w przypadku podjęcia lobbyingu, mimo braku przewidzianej ustawą rejestracji, grozić będzie sankcja w postaci grzywny. Przy czym zaznaczyć tu należy, że nie rodzaj kary grożącej w takim przypadku, lecz określenie jaki podmiot jest do tego uprawniony, a po drugie jej wysokość budzą wątpliwość. Wyjaśnić bowiem trzeba, że projekt przewiduje grzywnę w wysokości od 3000zł do 25 000zł. I mimo możliwości powielania tej sankcji w przypadku nie zaniechania tego rodzaju procederu, wydaje się jednak, że jest to zbyt łaskawa kara, gdy zważy się jakie korzyści majątkowe może przynieść określona decyzja, wobec której działania podejmują lobbyści. Wydaje się ponadto, że właściwszym organem kompetentnym do nałożenia tego rodzaju sankcji jest niezawisły sąd niż Minister, który przecież wedle założeń tego projektu sam miałby prowadzić rejestr. Wprawdzie przewidziano możliwość złożenia skargi na decyzję Ministra o wymierzeniu kary pieniężnej do NSA, tym niemniej taka konstrukcja może budzić zastrzeżenia.

W świetle przytoczonych powyżej argumentów, należy przychylić się do tezy, iż obecnie w państwie prawa wymagać powinno się przyjęcia ustawy o działalności lobbyingowej. Wprawdzie doświadczenia europejskie są w tym zakresie znikome, tym niemniej można i trzeba odwołać się w tym zakresie do osiagnięć innych pozaeuropejskich krajów, a zwłaszcza USA. Trzeba jednak bardzo mocno podkreślić, że ustawa o działalności lobyingu nie zlikwiduje zapewne korupcji w życiu publicznym. Bo też lobbying nie powinien być utożsamiany ze zjawiskiem płatnej protekcji. Zadaniem tej ustawy jest przede wszystkim wprowadzenie mechanizmów pozwalających na zapewnienie jawności działania organów władzy publicznej oraz grup nacisku. I w tym zakresie projekt ustawy realizuje ten cel, mimo zauważalnych i wskazanych powyżej pewnych wattpliwych rozwiązań. 


\section{Summary}

The paper is devoted to the issue of lobbying. It attempts to define the notion as well as it discusses legal regulations of this social phenomenon both in the USA and in several countries of the European Union. This provides a background for the presentation of a draft act on lobbying drawn by the Ministry of Internal Affairs and Administration in 2003. The author discusses the provisions of the legal act one by one simultaneously submitting his motions de lege ferenda. 